\title{
Diphenylalkylamine 誘導体の薬理学的研究
}

\author{
(1) 1,2-Diphenyl-1-dimethylaminoethane $\mathrm{HCl}$ \\ の光学異性体の作用比較
}

\author{
藤 村一川 井清尚 \\ (京都大等化学研究所) \\ (昭和35年 1 月 9 日受付[特])
}

緒言

元来 Morphine 仙諸種の作用を有するむのであるが，その強力な鎮痛効果は，㹨義の痛覚中枢以外に多数の 作用点を有し，その綜合的作用の結果として得られるものであり，同時に不快な副作用を暗有するものと考えら れる. 従って Morphine の構造を簡易化し，且つ部分的修飾するととにより，之の作用点をも可及的に分離し得 るのではないかと考壳，私迲は先ず Morphine 構造を最も簡易化し，A環とC環及びその間を連絡する Alkylamine の部分支取り上げた，特に Diphenylethylamine 誘導体が単独鎮痛効果を発揮し得る最少単位構造であ ると考光たからである．従来の甚だ多数のこの種誘導体については，その鎮痛効果は動物実験的に微弱なもの少 数が発見されたに過ざない゙．しかもてれまでの研究には大部分ラセミ体を用いて試験されている. Morphine或 は合成鎮痛凨の多くは光学活性体であるので，私達は2 先に多数の誘導体を合成して，てれを更に光学分割し， 鎮㴼作用，毒性に就いてスクリーニングを試みだ結果，Diphenylethylamine 誘導体中 Amine の 3 級化，且つ その光学異性体中左旋体が最も効果が大であることを認めたので，今回更に Morphine 及び Methylpropamine 等との構造作用関係について検澍すると共に，光学翼性と楽理作用との関係にも新知見を加えんとして，1,2Diphenyl-1-dimethylaminoethane HCl の光学異幽体間の一般薬理作用の比較を試みた。

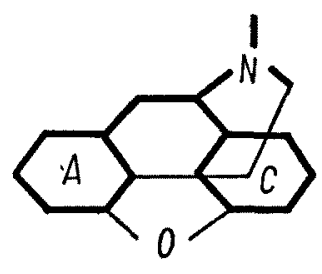

Morphine 霄格

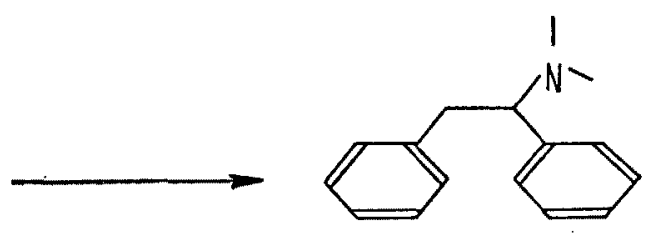

Diphenylethylamine

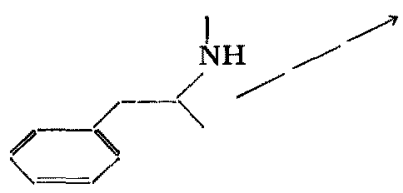

Methylpropamine 新格

1,2-Diphenyl-1-dimethylaminoethane HCl の电学異性体の曧点及ざ比旋光度は下記の如くである. 


$\begin{array}{lccc} & & \mathrm{mp} \mathrm{C} & {[\alpha]_{\mathrm{D}}^{20}\left(\mathrm{H}_{2} \mathrm{O}\right)} \\ \text { 左 旋 } & \text { 体 (1) } & 218 \sim 219 & -91.7 \\ \text { 右 旋 } & \text { 体 (d) } & 218 \sim 219 & +90.3\end{array}$

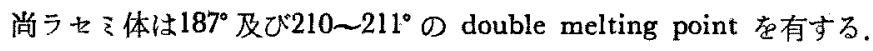

\section{実 験 成 續}

\section{1）毒 性}

マウス腹腔内投与㭙の症状は少量では鎮静状を呈し，0.5 $\mathrm{mg} / 10 \mathrm{~g}$ 以上の投与では與鹤状態に变じ，強直性痤

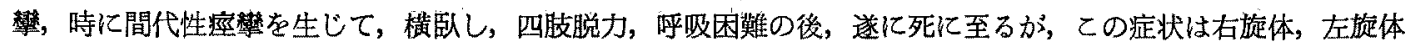

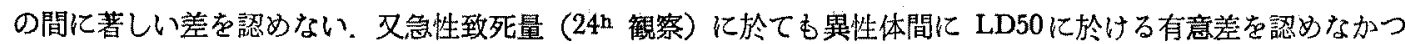

第 1 表. 毒性及び Haffner 法湾る鎮演作用比較.

\begin{tabular}{|c|c|c|c|c|c|}
\hline \multirow{2}{*}{ 異 } & \multirow{2}{*}{ 性 } & \multirow{2}{*}{ 体 } & \multirow{2}{*}{$\begin{array}{l}\text { LD50 mg/10g i. } p . \\
\text { (95\% limits) }\end{array}$} & \multicolumn{2}{|c|}{ ED50 mg/10g i. p. (95\% limits) } \\
\hline & & & & 独 & 䦓䧺量 Morphine 加 \\
\hline 左 & 旋 & 体 & $1.30(1.20 \sim 1.41)$ & $0.35(0.25 \sim 0.48)$ & $0.11(0.07 \sim 0.18)$ \\
\hline 右 & 旋 & 体 & $1.45(1.32 \sim 1.58)$ & 0 & $0.5 \mathrm{mg} \rightarrow \mathrm{Ca} 50 \%$ \\
\hline 5 & t $\Sigma$ & 体 & $1.23(1.02 \sim 1.49)$ & $0.5 \mathrm{mg} \rightarrow \mathrm{Ca} 20 \%$ & $0.16(0.13 \sim 0.21)$ \\
\hline
\end{tabular}

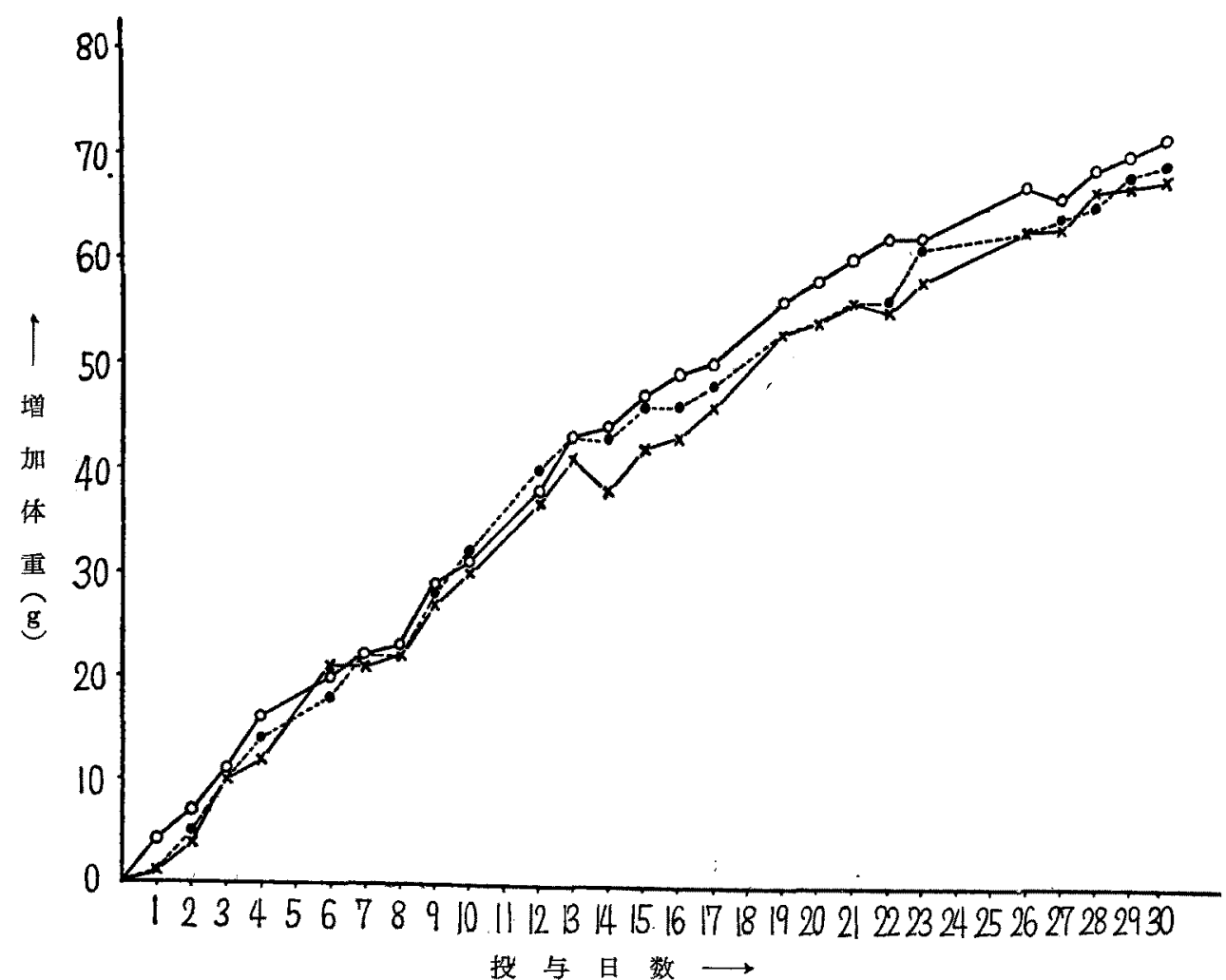

第 1 図，連続投与によるラット体重曲線。

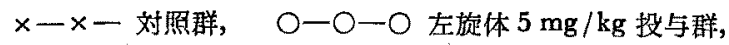
斌験開始時和均体正 $55 \pm 5 \mathrm{~g}$ (1 群20匹)。 
た（第 1 表）．又幼若雄性ラっト（実験開始時 1 群20匹の平均体重 $55 \pm 5 \mathrm{~g}$ ）に毎日 1 回 $5 \mathrm{mg} / \mathrm{kg}$ 腹腔内に 30 日 間連綕投与した場合，乙の期間中全く異常は認められず且つ体重增加は両異性体共に対照群と変らない(第 1 図).

2）鎮痛作用

a) Haffner 法：本法で測定すると単独投与時に左旋体のみ ED500算定が可能で，右旋体は全く作用を認め ず，亏セそ体では $0.5 \mathrm{mg} / 10 \mathrm{~g}$ で約 $20 \%$ の陽性率を示す、又閶値量 Morphine $(0.05 \mathrm{mg} / 10 \mathrm{~g} \mathrm{s.c.)}$ 加の場合は左

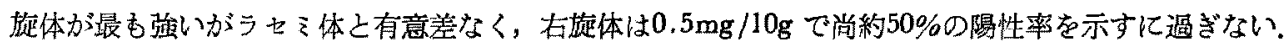

b） D'Amour-Smith法 (95 Volt, 250W 赤外ランプ使用)：本法に於ても反応時間が15 以上延長したものを陽 性とすると，左旋体は0.5 mg投与で55\%，ラセ之体は10\%の鎮痛作用を示すが右旋体は全く作用を認めなかつた。

c） Morphine (M) 及び Tremorine ( $)^{8)}$ との併用による镇痛作用の協力と拮抗 (Haffner 法)：左旋体は $\mathbf{M}$, Tの鎮痛作用に共に相加的協力を示すが，右旋体は両者に対して拮抗を示し，特にTに対しては完全な拮抗を認

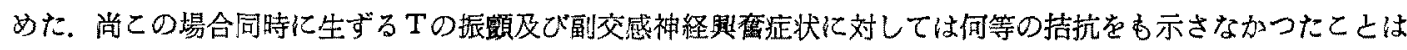
甚だ興昧深い.

第 2 表。併用に依る Morphine 及び Tremorine の鎮痛作用に対する㙝力，拮抗 (Haffner 法).

\begin{tabular}{c|cc}
\hline Morphine mg/10g s. c. & 左旋体 $0.4 \mathrm{mg}$ 併用 & 右旋体 $0.4 \mathrm{mg}$ 并用 \\
\hline 0.05 & $60 \%$ & $0 \%$ \\
0.10 & $80 \%$ & $50 \%$ \\
0.15 & $100 \%$ & $80 \%$ \\
0.20 & - & $50 \%$ \\
\hline Tremorine mg/10g s.c. & 左旋体 $0.4 \mathrm{mg}$ 併用 & 右旋体 $0.4 \mathrm{mg}$ 併用 \\
\hline 0.05 & $40 \%$ & $0 \%$ \\
0.10 & $60 \%$ & $0 \%$ \\
0.15 & $(0.2 \mathrm{mg}$ 并用 $\rightarrow 60 \%)$ & $(0.2 \mathrm{mg}$ 併用 $\rightarrow 30 \%)$ \\
0.15 & $80 \%$ & $0 \%$ \\
0.20 & $90 \%$ & $0 \%$
\end{tabular}

但し表中\%は1群10匹中の鎮痛作用陽性率を示す。

\section{3) Methylhexabital Na (MHA) 睡眠に対する協力作用}

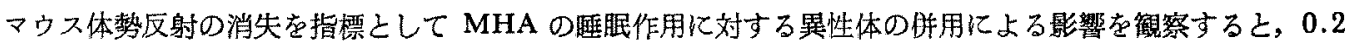

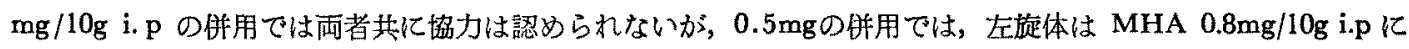
よる平均睡眠時間㕝明らが延長せしめる。然し，同量の右旋体では尚協力作用は明かでない（第 3 表)，尚又 MHA の無効量である $0.25 \mathrm{mg}$ 之異性体 $0.5 \mathrm{mg}$ の併用では左旋体のみか $90 \mathrm{~m}$ 迄 $50 \%$ の反射消失を示した。一方右 旋体は全く体勢反射の消失を認めなかった。

第3 表、Methylhexabital 睡眠化対する協力作用（マウス）。

\begin{tabular}{|c|c|c|c|}
\hline 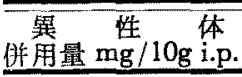 & $\begin{array}{c}\text { MHA } \\
\text { 用量 } \mathrm{mg} / \mathrm{l} 0 \mathrm{~g} \text { i.p. }\end{array}$ & 平均崕眠時間（分） \pm S.E. & 延長比 \\
\hline 左旋体対照 & 0.8 & $123 \pm 13.8$ & 1.00 \\
\hline 0.2 & 0.8 & $137 \pm 17.8$ & 1.11 \\
\hline 0.5 & 0.8 & $205 \pm 23.1$ & 1.66 \\
\hline 右旋体対照 & 0.8 & $127 \pm 17.3$ & 1.00 \\
\hline 0.2 & 0.8 & $137 \pm 20.5$ & 1.08 \\
\hline 0.5 & 0.8 & $163 \pm 17.7$ & 1.28 \\
\hline
\end{tabular}

\section{4) 体温に対する影担}

マウス直腸体温に及祦す影響を観察すると各 $0.4 \mathrm{mg} / 10 \mathrm{~g}$ の腹腔内投与により，左旋体は投与後 $60 \mathrm{~m}$ を底とす 
る下降を示すが，右旋体は逆に投与-30m 後を頂点とする軽度の上昇を認めた，尚うセミ体は殆んど体温に影響を 示さない(第 4 表).

第 4 表. マゥス体温に対する異性体の影響.

\begin{tabular}{|c|c|c|c|c|c|c|}
\hline \multirow{2}{*}{\multicolumn{3}{|c|}{$\begin{array}{|ccc|}\text { 異 } & \text { 性 } & \text { 体 } \\
\text { 投与量 } & 0.4 \mathrm{mg} / 10 \mathrm{~g}\end{array}$}} & \multirow{2}{*}{$\begin{array}{l}\text { 投与前体温 } \\
{ }^{\circ} \mathrm{C} \pm \mathrm{S} . \mathrm{E}\end{array}$} & \multicolumn{3}{|c|}{ 投与後経過時間に於ける直腸温 } \\
\hline & & & & $30 \mathrm{~m}$ & $60^{\mathrm{m}}$ & $120^{\mathrm{m}}$ \\
\hline 左 & 旋 & 体 & $38.2 \pm 0.09$ & $37.2 \pm 0.19$ & $36.6 \pm 0.16$ & $37.1 \pm 0.23$ \\
\hline 右 & 旋 & 体 & $38.1 \pm 0.10$ & $38.9 \pm 0.16$ & $38.8 \pm 0.21$ & $38.4 \pm 0.18$ \\
\hline ラ & セ z & 体 & $38.2 \pm 0.06$ & $38.4 \pm 0.11$ & $38.0_{ \pm 0.14}$ & $38.0 \pm 0.21$ \\
\hline
\end{tabular}

註：表中数字は1群10匹の平均体温と標淮誤差を示す。

\section{5) 鎮 咳 作 用}

先に藤本 ${ }^{4}$ は犬を用いて，電気的，機械的，及び化学的刺激を加えて発咳せしめ，咳発作時の腹圧の变化を 利用しててれを煤紙上に記録する方法に依って本左旋体の鎮咳効果を測定し，その最少有效量 (4〜8mg/kg i.v) は,いづれの刺激方法の場合に於ても Hydrocodeine の約 2 倍量を示すことを認めた，尚，右旋体は麗気的剌激 法のみを実施したが，10mg/kg の投与に於ても殆んど鎮咳効果を示さなかった。

6) Amineoxidase (AO) 活性及ひ媨組織呼吸に及ぼす影霜

先に私達はす諸種の薬物の興窟作用とそれ等が Amine-oxidase 活性及び脳組織呼吸に対する阻害作用との 関係に就て検討し特にその覚醒効果と阻害作用とが平行性を有しないことを知ったのであるが，本誘導体汇就て は，その右旋体及びラセミ体が覚醒アミンに倍する最む強力な家鬼肝 $\mathrm{AO}$ 活性の阻害作用を示し，左旋体は甚し く劣る作用しか示さなかった，又家象大脳皮質組織呼吸に対してむ右施体の方が左旋体より強い抑制を示した (第 5 表 1,2 ).

第 5 表，1。家匝肝Monoamine oxidase の Tyramine $\left(2 \times 10^{-8} M\right)$ 酸化に及ぼす影望。

\begin{tabular}{|c|c|c|c|c|}
\hline & 用 & 量 & $\mathrm{O}_{\mathrm{a}}$-消費量 $(\mu \mathrm{L})$ & 阻 害 $(\%)$ \\
\hline \multicolumn{3}{|c|}{ Control } & $25.0 \pm 0.98$ & \\
\hline 有 & 旋 & \multirow{3}{*}{$2 \times 10^{-s} \mathrm{M}$} & $6.1 \pm 0.53$ & 75.6 \\
\hline 左 & 旋 & & $17.9 \pm 0.5 \mathrm{l}$ & 28.4 \\
\hline F & 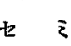 & & $9.9 \pm 0.55$ & 60.4 \\
\hline
\end{tabular}

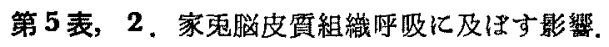

\begin{tabular}{|c|c|c|c|c|c|c|c|c|}
\hline & “用 & 量 & $\mathrm{Qo}_{2}$ & 用 & 量 & $\mathrm{Qo}_{3}$ & 抑 制 & $(\%)$ \\
\hline \multirow{4}{*}{$\begin{array}{l}\text { Control } \\
\text { 右旋体 } \\
\text { 左旋体 } \\
\text { ラセ之体 }\end{array}$} & \multirow{4}{*}{\multicolumn{2}{|c|}{$2 \times 10^{-3} \mathrm{M}$}} & $9.3 \pm 0.19$ & \multirow{4}{*}{\multicolumn{2}{|c|}{$5 \times 10^{-3} \mathrm{M}$}} & $10.0 \pm 0.41$ & $2 \times 10^{-3} \mathrm{M}$ & $5 \times 10^{-3} \mathrm{M}$ \\
\hline & & & $8.2 \pm 0.25$ & & & $6.7 \pm 0.38$ & 11.8 & 33.0 \\
\hline & & & $9.1 \pm 0.13$ & & & $7.7 \pm 0.36$ & 2.1 & 23.0 \\
\hline & & & $9.0 \pm 0.49$ & & & $7.1 \pm 0.35$ & 3.2 & 29.0 \\
\hline
\end{tabular}

\section{7）家鬼血糖に及ぼす影望}

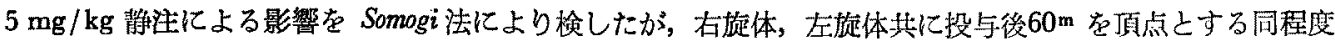
の軽度の血糖上昇を来し，両者の間传有意差を認めなかった，尚 Morphine $5 \mathrm{mg} / \mathrm{kg}$ の投与では投与後 $120 \mathrm{~m}$ を 頂点とする約 $60 \%$ の増加を認めた。 
第 6 表. 家 秘血糖 增 加率 (Somogi 法).

\begin{tabular}{|c|c|c|c|c|c|c|c|}
\hline \multirow{2}{*}{ 異 } & \multirow{2}{*}{ 性 } & \multirow{2}{*}{ 体 } & \multicolumn{2}{|r|}{ 投 } & \multirow{2}{*}{$\frac{\text { 与 }}{120^{\mathrm{m}}}$} & \multirow{2}{*}{$\frac{\text { 後 }}{180^{\mathrm{m}}}$} & \multirow[b]{2}{*}{$240^{\mathrm{m}}$} \\
\hline & & & $30 \mathrm{~m}$ & $60^{\mathrm{m}}$ & & & \\
\hline 左 & 旋 & 体 & $16 \pm 4.8$ & $18 \pm 6.0$ & $11 \pm 7.2$ & $8 \pm 6.7$ & $6 \pm 3.5$ \\
\hline 右 & 旋 & 体 & $9_{ \pm 6.9}$ & $16 \pm 7.1$ & $14 \pm 6.3$ & $13 \pm 5.8$ & $9 \pm 4.8$ \\
\hline
\end{tabular}

注）表中数字は $5 \mathrm{mg} / \mathrm{kg}$ i.v. 投与時の家鬼 5 例の血糖増加平均\%土S.E.

\section{8）犬，猫血圧に及ぼす影翼}

体重 5〜10kg の犬, 及び体重 2 4 kg の猫を用い, Isomytal Na 50 60mg/kg i.p. 麻醉下に型の如く頸動 眽圧に対する薬物投与の影響を検した処，犬では $1 \mathrm{mg} / \mathrm{kg}$ の股静脈投与により左，右両異性体共に軽度 $(10$ 20 $\mathrm{mm} \mathrm{Hg}$ ）且つ持続性の血圧上昇を示した，尚ての場合呼吸に対する抑制は殆んど認められなかった，又反覆投 与による Tachyphylaxis は認められない. 猫に於ても両異性体共に大の場合之略々同程度の上昇を認めた. 然

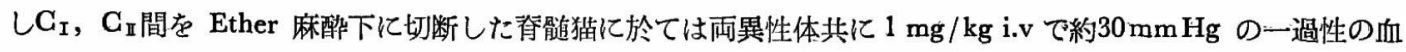
圧下降を镜た（第 2 図，第 3 図，第 4 図).
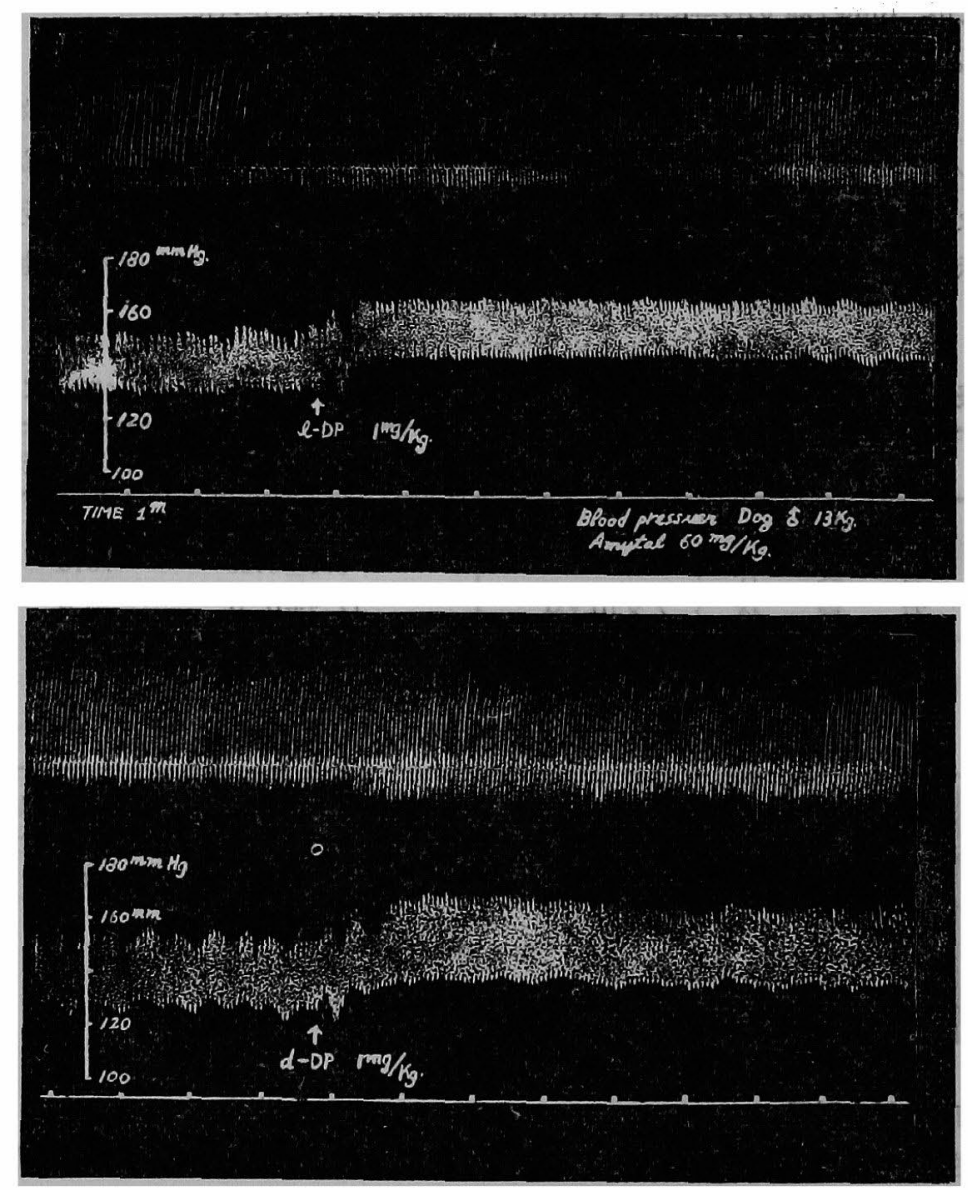

第 2 图，異性体の犬血圧，呼吸に対する影響。

上図 左旋体投与. 下図 右旋体投与. 


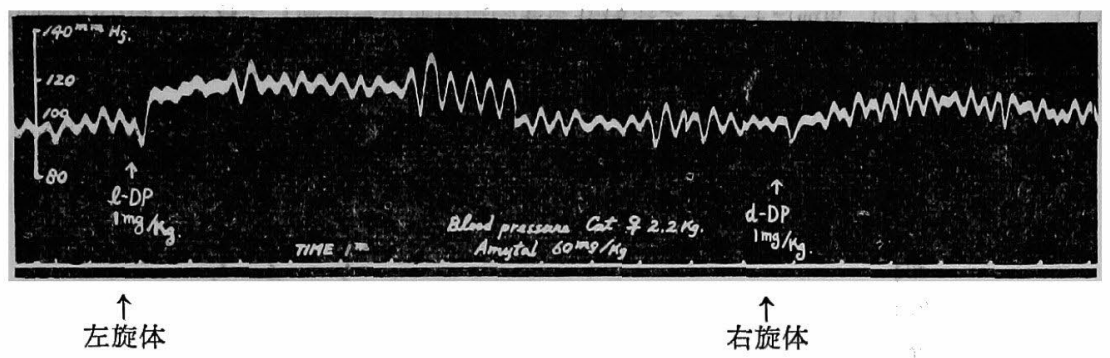

第 3 図. 異性体の猫血圧に対する影響.

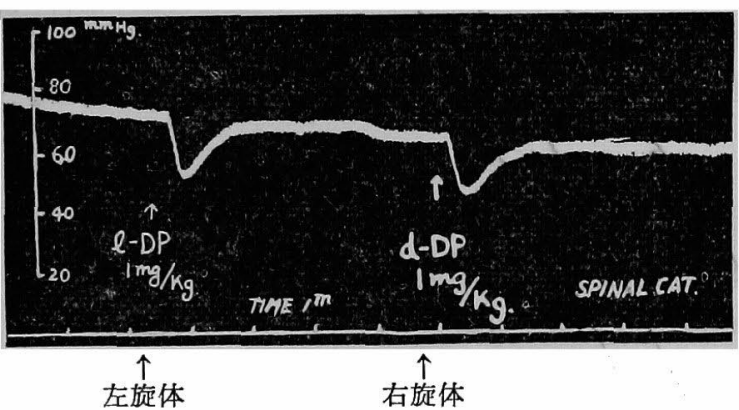

第 4 図，異性体の脊娟道猫血圧に対する影響。

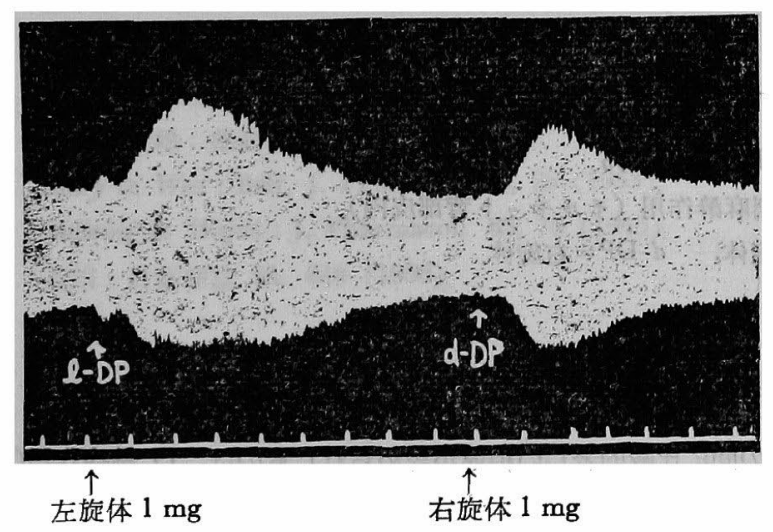

第 5 図. 家鬼耳殼血管灌流に及ぼす影嘅（滴数計使用）.

\section{9）家兔耳殼血管に対する影翼}

Pissemski 法により摘出家鬼耳殼血管を Ringer 液を以て灌流し, 血管カニューレに連 結するゴム管より面物を注入したが，左右両 異性体共にその $1 \mathrm{mg}$ の注入は血管の収縮を 生ずることを認めた（第 5 図）.

10）摘出腸管及び気管筋に於ける镇痓作 用

家鬼の摘出腸管に於ける $\mathrm{ACh}\left(10^{-7}\right)$, Histamine $\left(10^{-7}\right), \mathrm{BaCl}_{2}\left(10^{-4}\right)$, 及びモル モット摘出腸管に於ける Histamine $\left(10^{-7}\right)$ による収縮を両者共抑制したがその最少抑制 㵋度は $5 \times 10^{-5} \sim 2 \sim 4 \times 10^{-6}$ で強くない. 又モルモットの摘出気管筋 (輪状連鎖標本) $\left.{ }^{6}\right)$ に於ける $\mathrm{ACh}\left(10^{-6}\right)$, Hist $\left(10^{-6}\right)$, 及び家 鬼気管筋に於ける $\mathrm{ACh}\left(10^{-6}\right)$ による収縮に 対してむ左右共に同程度の抑制作用を示すが， 余り強くない（第 7 表，第 8 表).

11) 局所麻醉作用

a）表面麻酔作用 : 家鬼角膜に被検薬の $1 \%$ 溶液0.1 cc 点眼し，5m 毎に剌激毛で角 膜中心部を 5 回宛刺激し，瞬目反射が 2 回以 下の場合を陽性之見なして麻酔持続時間を测
第 7 表. 摘出晹管に於ける鎮痤作用 (最少抑制濃度).

\begin{tabular}{|c|c|c|c|}
\hline 異性体 & $\begin{array}{l}\text { 抗-ACh } \\
\left(1 \times 10^{-7}\right)\end{array}$ & $\begin{array}{l}\text { 抗 Hist* } \\
\left(1 \times 10^{-\rightarrow}\right)\end{array}$ & $\begin{array}{l}\text { 抗-Bacl } \\
\left(1 \times 10^{-4}\right)\end{array}$ \\
\hline 左旋体 & $2 \sim 4 \times 10^{-6}$ & $2-4 \times 10^{-5}$ & $5 \times 10^{-5}$ \\
\hline 右旋体 & $2 \sim 4 \times 10^{-6}$ & $5 \times 10^{-5}$ & $1 \times 10^{-5}$ \\
\hline ラセえ体 & $2 \sim 4 \times 10^{-6}$ & $5 \times 10^{-5}$ & $5 \times 10^{-5}$ \\
\hline
\end{tabular}

*モルモット摘出腸管使用，他は家鬼。
第 8 表. 摘出気管筋に於ける鎮痤作用(最少抑制濃度).

\begin{tabular}{l|ccc}
\hline 異性体 & $\begin{array}{c}\text { 抗-ACh } \\
\left(1 \times 10^{-6}\right)\end{array}$ & $\begin{array}{c}\text { 抗-Hist } \\
\left(1 \times 10^{-6}\right)\end{array}$ & $\begin{array}{c}\text { 抗-ACh* } \\
\left(1 \times 10^{-6}\right)\end{array}$ \\
\hline 左顷 体 & $1 \sim 5 \times 10^{-5}$ & $1 \times 10^{-5}$ & $1 \times 10^{-5}$ \\
右 旋体 & $1 \times 10^{-5}$ & $1 \times 10^{-5}$ & $2 \times 10^{-6}$ \\
ラ七ミ体 & $1 \sim 5 \times 10^{-5}$ & $1 \times 10^{-5}$ & $2 \times 10^{-6}$
\end{tabular}

* 家鬼気管筋使用, 他はモルモット

定し，各 5 例の平均を求めた処，左右異性体間には差なく，共に Procaine より稍々長い持続時間を示した。即 ち Procaine $10 \pm 1.6^{\mathrm{m}}$ 亿対し左旋体 $15 \pm 2.9 \mathrm{~m}$, 右旋体 $14 \pm 1.3 \mathrm{~m}$ である.

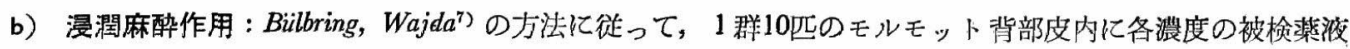


0.2ccを注入し， $5^{\mathrm{m}}$ 每に 6 回，30mにわたって注射針で薬物注射部位を刺激して疼痛反射の久除回数を記録した 所, 左旋体が右旋体よりやや強く，として両者共に Procaine よりす強い作用を有することを認めた（第 6 図）.

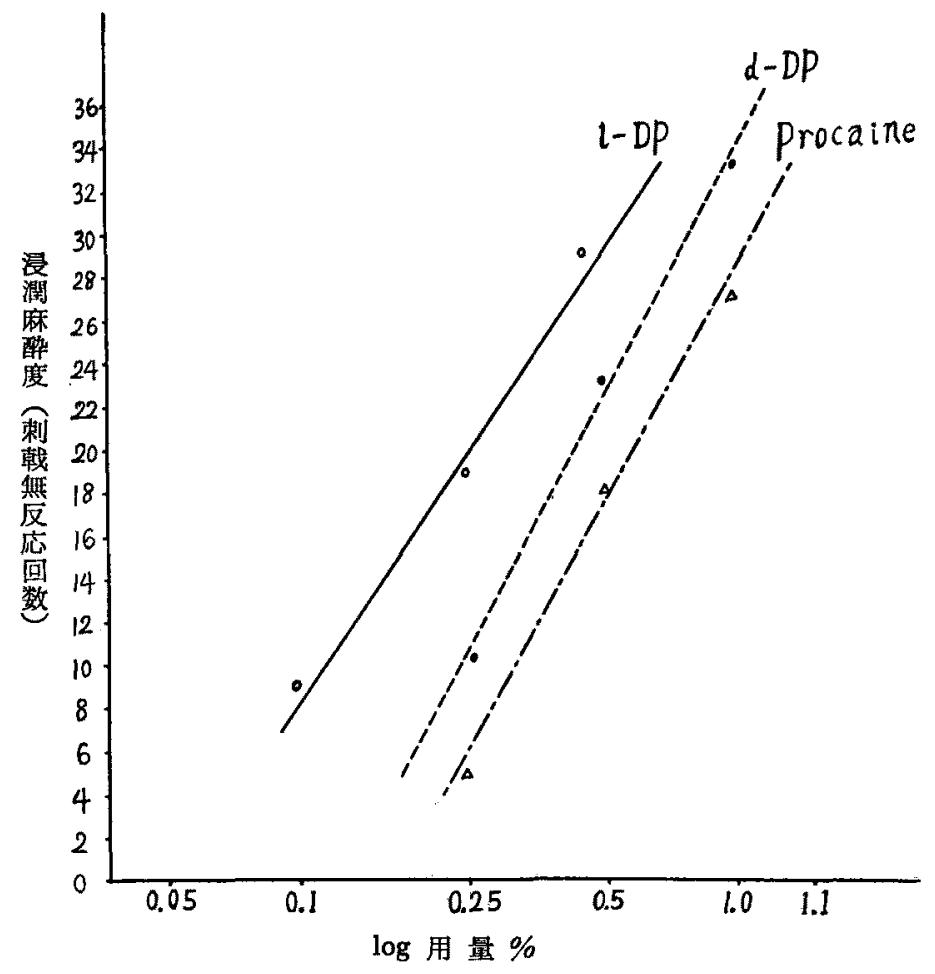

第 6 図. 異性体の浸潤麻醉作用（モルモット背部皮内）。

l-DP = 左旋体,$\quad d-\mathrm{DP}=$ 右旋体.

\section{考察並びに総括}

以上の実験成績から，左旋体と右旋体の作用の間に比較的著しい相違が認められたものは，1）鎮痛作用( マ ウス）は左旋体は有するが，右旋体は有しない，左旋体の鎮痛効果は Haffner 法では略々 Codeine のそれと等 しいが D.S 法では Codeine に比して著しく弱い，又 Morphineゃ Tremorine の鎮痛作用に対して左旋体は 協力的であるが，右旋体はむしろ拮抗的である．乙のととは，ラセる体が左挍体化比して著しく弱く，ED50の 算定不可能であったととと何等加の関係を有るものと考元られる。

2）鎮陔作用（犬）す左旋体は Hydrocodeine $01 / 2 \sim 1 / 4$ 程度の作用を有するが右旋体は殆んど無胶である.

3）マゥスの Methylhexabital 睡眠作用に対して左旋体は協力的であるが，右旋体は協力しない.

4）マウス体温を左旋体は下降，右旋体は上昇せしめる，乙の㑯向は Propamine 類にも認められる.

5） Amine-oxidase 活性の阻害作用は両者共に有するが，右旋体の方が著しく，Methylpropamine のそれ よりも尚著しく強い，この成績は鎮痛作用，覚醒作用と阻害作用との間何等の平行性も無いととをものがたっ ている.

次に左右異性体間に著しい美を認め得なかったるのは，1）毒性（マウスの中毒症状並びに致死量）では両者

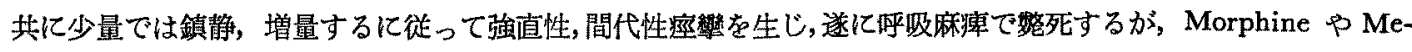
thylpropamine にみられる活発な遇動興鹪は認められない，又 LD50にあ有意差はなく，上記の如き著明な作用 の相違が毒性に余り影響していないことは興味深い. 
2）家鬼血糖に対しては両者共に同程度の軽微な上昇を認めた。一般に鎮痛剂の血糖上昇作用はその鎮痛作 用と平行性を有するあのであるがタ，鎮痛作用のない右旋体でも軽度乍ら上昇をみたととは眼味がある。

3）犬，猫血压に対しては共に軽度のやや持続性の上昇を認めた。持続性の下降を生ずる Morphine 上は逆 である，尚春䯣猫では下降を示すが一過性である。

4) 摘出滑平筋の $\mathrm{ACh}$, Histamine, $\mathrm{BaCl}_{2}$ 痙攀に対しては両者共に略々同程度の抑制作用を示すがこの作 用は余り強くない。

5）摘出家鬼耳㲄血管灌流下に共に血管収縮作用を有する。

6）确所麻醉作用は共に同程度の Procaine に稍々優る作用を有している。

この様な分類加ら本化合物は一般的に中权作用に於て異性体間の作用の相違が著しく，末梢作用に於ては左， 右略々同様の効果を示すととが判明した。

又上記成樍から化学構造上近縁性を有する Morphine ア Methylpropamine の作用と多くの点で異っている ことも認められたので特に鎮痛薬としての左揟体に就て更に詳細な実験を追加しつつあるがその結果は次報に譲 る.

\section{引用青目}

1) Dodds et al. : J. Physiol. 104, 47 (1945), Dodds et al. : Nature 151, 614 (1943), Burger : Medicinal Chemistry Vol. 1, 345 (1951), Suter : Medicinal Chemistry Vol. 1, 390 (1951), Holck et al. : J. Amer. Pharm. Assoc. Sci. Ed. 39, 354 (1950).

2) 荻生, 藤村, 山川: 薬誌 80, 3 号揭载 $(1960)$.

3) Everett et al. : Fed. Proc. 15, 420 (1956); Chen : J. Pharmacol. 124, 73 (1958); 藤村たち：第18回日本薬 理学会近畿部会記事.

4) 藤本: 日薬理誌 54，1307 (1958)，54，1317 (1958).

5) 藤村, 大幡：薬誌 78, 1055 (1958).

6) Mary \& West : Brit. J. Pharmacol. 8, 26 (1953).

7) Builbring \& Wajda: J. Pharmacol. 85, 78 (1945).

8）石川：日薬理誌 52, 646 (1956). 